\title{
DETERMINING THE FIT OF A TECHNOLOGY STRATEGY: AN APPLICATION OF THE “FIT AS GESTALT” PERSPECTIVE
}

\author{
Guenther Schuh $^{1^{*}}$, Hedi Bachmann², Simon Ryschka ${ }^{3}$ \\ *1Laboratory for Machine Tools and Production Engineering WZL, RWTH Aachen University, Aachen, Germany \\ ${ }^{2}$ Cerobear $\mathrm{GmbH}$, Herzogenrath, Germany \\ ${ }^{3}$ Department of Technology Management, Fraunhofer Institute for roduction Technology IPT, Aachen, Germany \\ *lG.Schuh@wzl.rwth-aachen.de; ${ }^{2}$ Hedi.Bachmann@cerobear.com; ${ }^{3}$ Simon.Ryschka@ipt.fraunhofer.de
}

\section{*Corresponding Author: -}

Email: G.Schuh@wzl.rwth-aachen.de

\begin{abstract}
: -
Studies have shown that the success of different technology strategies varies with the conditions under which they are derived, e.g. internal or external boundary conditions. Thus, technology strategies fitted to the requirements of an enterprise are a key success factor. Until now, there is little research work done to determine the fit of a technology strategy. Therefore, in our research project, we developed a method to analyse and determine the fit of a technology strategy of an enterprise with its specific internal organizational and strategic context as well as with its external boundary conditions. Prior research on the interrelationships between technology strategy and influencing factors is mainly focused on single parameters. This article brings an integrated view to the fit of a technology strategy by applying the »fit as gestalts" perspective as well as cybernetic reasoning to the research field of technology strategy.
\end{abstract}

Keywords: - Technology Strategy, Strategy Integration, Evaluation of Sstrategy Fit, Internal Alignment, External Alignment

\section{(c) $(\$)$}




\section{INTRODUCTION}

Beginning in the 1980s, technologies are considered a relevant success factor for enterprises [33]. In the course of this development, technology management gained importance within theory and practice ([44], [67]). Main task of strategic technology management is the formulation of explicit technology strategies [77]. This has proven successful: several empirical studies show that enterprises with an explicit technology strategy operate more successful than competitors without an explicit technological long-term orientation ([21], [28], [59], [82]). Especially nowadays, with increasingly dynamic environments, decreasing return from technological investments and increasing complexity of technological developments, long-term technological orientation becomes more important.

However, as companies grow in size and become increasingly formalized, the in-company strategy cascade is becoming more complex. In addition to the business and competitive strategies, a number of regional and cross-divisional as well as crossfunctional strategies can be found [4]. In addition to these, there are new developments such as the sustainability strategy [76] as well as the classical cross-sectional strategies such as technology or innovation strategy, which are pursued by companies of all sizes ([63], [66]).

Due to the cross-sectional character of the technology strategy, it is vital to integrate it within the company-specific strategy cascade ([26], [41], [64], [77]). It is also essential to adapt it to the prevailing conditions under which the company is operating. Empirical studies have shown that the success of different technology strategies varies with the conditions under which they are derived ([39], [80], [82]). Factors which influence the success of a technology strategy range from the characteristics of a company, through the environment in which the company operates and the size of the company to the organizational and strategic context of the company ([18], [23], [77], [82]).

In practice, however, strategic decisions are frequently made on different hierarchical levels and in various business areas ([22], [62]). Due to the complex strategic boundary conditions, it is not possible to coordinate the technology strategy with the strategic decisions previously taken by other business areas or functions in a simple way. It is therefore not uncommon in industrial practice, for new strategies to be introduced without synchronizing them with existing parameters and strategies. In practice this is a problem since technology strategies whose fine-tuning was not context-specific and therefore not fitted, may result in wasted resources coupled with a loss of competitive advantage [82].

However, it is not sufficient to infer an appropriate technology strategy from the current situation in order to survive today's turbulent competitive environment. Technology strategies must be updated continuously in order to adapt to rapidly changing parameters. For companies, however, it is both time consuming and expensive to draw up a new strategy every time the parameters change. It would be more helpful to have an opportunity to review the fit of the technology strategy when the parameters change. Currently, companies do not have this option.

In this paper, we investigate the fit of a technology strategy under the »fit as gestalt «perspective [72] and cybernetic way of thinking. We present four criteria, which cover the main aspects to determine the fit of a technology strategy from our perspective as well as an outlook for their operationalization and application. This paper is organised in five sections. In the following section II the theoretical background, necessary for the development of the criteria is displayed. Section III discusses and constitutes the criteria. In section IV a prospect for the application of the criteria is given. The paper concludes with a discussion and propositions for further research in the field of technology strategy fit in section V.

This paper aims at contributing to technology strategy theory by increasing the understanding of the complex interactions between technology strategy and its internal and external boundary conditions. By applying the »fit as gestalt « perspective as well as cybernetic reasoning to the research field of technology strategy the control and handling of the complex interactions between technology-based strategic decisions and influencing factors is made possible. This is a first starting point to a systematical derivation of measures and recommendations for action to optimize the existing technology strategy of an enterprise.

\section{THEORETICAL BACKGROUND}

\section{Development Of Technology Strategy Research}

Technology strategy emerged as a recognized subject area in the late seventies and early eighties when it became a focus of research as a result of work conducted by Ansoff and Stewart [2] as well as Maidique and Patch [47]. Regarded as part of a technology-oriented competitive strategy, the subject came to the attention of various authors who inves-tigated it and developed it further. Technology strategy was not established as an independent entity until the mid-eighties ([33], [57]). This point marked the beginning of a growing commitment to this subject area. Distinctions can be drawn between various categories of research work. These categories are presented and discussed in relation to the work proposed

\section{A. Development Of The Contents Of Technology}

The focus of earlier research was on defining and limiting the subject area of technology strat-egy. Studies in this field focus on technology strategies both from a conceptual as well as from an empirical point of view ([1], [15], [19], [25], [30], [57], [68] [77]). The outcomes of this research works are decision fields and possible options of action for a technology strategy, embedded in a mostly theoretically derived framework. Whilst a generic definition of the aim of technology strategies appears in similar form in the works of a number of authors ([33], [57], [82]), there are very considerable differences both in research and in industrial practice related to the actual contents of a technology strategy: Beginning with the selection of appropriate technologies (e.g. [17], [47]) the technological competence level of the company (e.g. [82]), the timing of the market entry (e.g. [17], [47]), the technology source (e.g. [57], [82]), technology commercialization options (e.g. [29]), R\&D-intensity (e.g. [2], [16], breadth of the technology portfolio (e.g. [82]), focus on product- oder process technologies (e.g. [82]), technology protection (e.g. [25]) and new product rate (e.g. [21]) to a rather broad scope including organizational decisions (e.g. [2]), geographic orientation (e.g. [25]) and selection of 
industries or markets (e.g. [57], [21]). In this paper we refer to the term technology strategy as the combination of choices in the five dimensions technological competence level of the company (including R\&D-intensity), timing of the market entry, technology source, technology commercialization and breadth of technology portfolio.

\section{B. Research Studies In The Area Of »Fit« Of A Technology Strategy}

A third category of research studies addresses the relationships between the technology strat-egy and possible influencing factors (e.g. [11], [15], [23], [41], [82]). This category of research work aims at examining the influence of individual aspects (e.g. dynamics of competitive environment, company sizes) on the contribution of a technology strategy in companies. Thus the goal is not to explain the complex interactions which determine the overall fit of a technology strategy with its various kind of boundary conditions. The work presented here, builds a framework to integrate the various research results on influencing factors on the success of a technology strategy into a holistic approach to determine the fit of a technology strategy.

\section{1) Fit As Gestalt And Cybernetics As Basis For The Determination Of Fit}

The idea of determining the fit of a technology strategy based on a »fit as gestalt « [72] perspective, is built on contingency theory and its understanding that $\gg . .$. no strategy is universally superior, irrespective of the environmental or organizational context, ...« [72]. Accordingly, the fit is in this perspective of vital importance ([13], [71]). Often also called »alignment « [9], »match« [38] or »congruence « [60], it is an expression for the coordination of internal and external elements of a company among themselves and with the corporate strategies ([61], [83]). The motivation of the fit concept is the increase of the corporate success resulting from this balancing ([53], [83]). Basically, various types of fit can be distinguished. The most detailed consideration is due to [72]. He designs a classification scheme in which six different versions of fit are presented. The considerations of the paper proposed are based on the »fit as gestalt « perspective due to the high number of variables which have to be considered and the non-linear, complex relationships beweteen these variables [72]. The gestalt approach with Miller \& Friesen [52] as main representatives builts on the assumption that the success of organizations is based on the coherent configuration of their various variables. In this mindset, the examination of the influence of individual factors is considered to be a reduction of complexity and therefore a tampering of findings [46]. Thus a valuable analysis of an organization must comprise all variables, which describe the organization and its situation [51]. If the configurations of variables appear in a »coherent « way [72] or »temporary state of balance« [51] the configurations are called gestalts. There is the assumption that in reality only a limited number of gestalts for a particular situation exists [45]. This paper proposed follows the gestalt approach and states that certain configurations of technology strategic decisions and relevant aspects of the company's situation form coherent cluster, i.e. gestalts.

\section{2) Cybernetics And Complex Problem Solving}

To determine the fit of a technology strategy, it is necessary to control the complex interactions of technology strategic decisions and their relevant influencing factors. Cybernetics has proven successful in problem-solving within the context of complex organizations ([3], [37], [43]). Primarily developed to understand the communication and control of complex systems ([37], [43], [75]), cybernetics deals with non-linear interaction of different variables that influence each other simultaneously and thereby provoke a change or a modification of the system ([3], [20], [43]). Cybernetics was transferred to different science areas. Stafford Beer ([5], [7]) counts as the founder of management cybernetics. He obtained awareness by its »Viable System Model « [6]. The management cybernetics is due to Bertalanffy. He introduced the cybernetic loop and applied it to the management and control of companies [27]. The field of management cybernetics is to be understood as a theoretical framework, which aims to develop concepts regarding behaviour and structures of dynamic systems within the periphery of companies [27]. Within this framwork and influenced by systems theory, approaches emerged, which aim at methodically supporting the presentation and analysis of complex problems ([65], [69]). The most relevant approaches for the work proposed will be displayed in the follwing.

The »Methodology for qualitative system analysis«, developed by Jay Forrest ([31], [32]) supports the analysis of highly complex problems, based on qualitative system characteristics. The procedure is based on the analysis of the system under different points of view and builts on a dynamic balance between system maturity, network connectivity and turbulence. Five more perspectives complete the picture: system boundaries, feedback structures, stocks and flows, structural dependency and fitness complexity. System maturity describes the lifecycle in which the system is operating. Depending on the system maturity and the rate of turbulence of the surrounding environment a certain network connectivity of the system is needed for stability. The analysis of the system starts with the definition of system boundaries. The consideration of feedback structures as well as the analysis of stocks and flows is essential to derive knowledge on the system behaviour. The perspective of fitness complexity aims at analysing the interconnectedness of the system in order to gain insights on the future system development. Structural dependency arises, if more than one element of a model uses the same infrastructure. With increasing structural depency, the instability of the system increases as well.

The Viable System Model (VSM), developed by Stafford Beer ([6], [7]) counts as the classic model to design control systems for organizations [65]. The VSM is based on three principles: viability, recursion and autonomy [48]. Viable for Beer means the capability of a system to respond to environmental changes, even if they could not have been foreseen [40]. The recursion principle states that every viable system consists of viable sub-systems and is part of a superior viable system [7]. Following the recursion principle there is no total freedom of behaviour for any sub-system if not in 
the boundaries of the superior system [35]. Although they are stated a certain autonomy, this autonomy is not allowed to threaten the overall goal of the system ([8], [48]).

The methodology of system thinking, introduced by Ulrich, Gomez and Probst aims at facilitating the dealings with complex problems in companies ([54-56], [70]). It states that companies can be characterized by its entireness, interconnectedness, openness, complexity, patterns of behaviour, steerability and ability to develop. To apply the perspectives correctly, they developed a procedure, consisting of six steps.

Closely linked with this methodology, Vester developed his cybernetic sensitivity model ([73], [74]) which is based on biocybernetic principles and equally aims at analysing and solving complex problems. Its recursive and iterative structure comprises the description of the system via a set of relevant variables, the assessment of the variables with the help of a criteria matrix, the set-up of a cross-impact-matrix for the variables, the analysis of the roles of the distinct variables, the display of the cause-effect-diagramm underlying the system under consideration, the development and simulation of szenarios and last but not least the system assessment.

\section{3) Interim Conclusion}

Although the discussion of the development of technology strategy research in chapter II shows that procedures are available, which support companies in deriving their technology strategies for the first time, research still lacks procedures and methods, which enable enterprises to determine the fit of their already derived technology strategy, especially under changing boundary conditions. Furthermore, research on influences on technology strategies mainly considers singular influence factors and thus does not support enterprises within their complex environments. To meet the requirements of a high number of influencing factors with complex, non-linear relationships and interactions within companies, the research fields of gestalt perspective and cybernetics as well as concrete approaches to address the complexity were presented in chapter II. Based on this theoretical background, the criteria to determine the fit of a technology strategy will be derived in the following section.

\section{Criteria To Determine The Fit Of A Technology Strategy}

\section{A. Characterisation Of A Fitted Technology Strategy}

The term fit in relation to technology strategy is seldomly used in literatur until now. There is no possibility for companies to determine the fit of their technology strategy. In the following section the characteristics of a fitted technology strategy will be displayed. To assess, if a technology strategy fits to the enterprise, the following questions, which cover the main aspects to be considered while developing a technology straegy, have to be answered:

- Has the technology strategy been formulated in the right degree of detail?

- Does the chosen technology strategic position make sense given the internal and external boundary conditions of the specific technology field?

- Has a reasonible distribution of resources to the individual technology fields taken place?

These questions serve as guidance for the derivation of the criteria to operationalize the fit of a technology strategy.

\section{B. Operationalisation Of The Fit}

The determination of the fit of a technology strategy proved to be a complex problem, mainly due to the variety of influencing factors, which cannot be solved with conventional linear approaches. Therefore, the understanding of the fit of a technology strategy must be extended by including approaches of the fit as gestalt perspective as well as cyberntic thinking. Based on the findings of the theories and methods, discussed in section II of the paper, the following statements to determine the fit of a technology strategy can be made:

- following the argumentation of systems thinking, a complex problem can be described by its connection structures and cause-effect-characteristics [36]

- for the determination of the fit of a technology strategy the variables, which describe the situation under which the technology strategy is derived have to be identified. In doing so, the evaluation of the system boundaries according to Forrest ([31], [32]) is a major concern

- according to the presented methods of systems thinking, the relationships and interdependency of the variables have to be determined and displayed in a comprehensive and intuitive way [56]

- based on the »fit as gestalt« perspective ([51], [72]) the methodology for qualitative system analysis ([31], [32]), the Viable System Model [6], the methodology of system thinking ([54-56], [70]) and the cybernetic sensitivity model ([73], [74]) criteria will be derived, which allow the determination of the fit of a technology strategy. These criteria will be discussed in the following section.

In order to determine the fit of a system, the consistency $(C S)$ of the system is a necessary criterion (1). Is the consistency of a technology strategy $(C S(T S))$ with its boundary conditions assured, the level of fit $(F(T S))$ can be determined as follows?

- Following the reasoning of the fit as gestalt perspective, certain configurations of technology-strategic decisions and relevant characteristics of the company as well as environmental boundary conditions fit, if they form gestalts. These gestalts are characterized by the internal stability and coherence of their variables ([51], [72]). Thus this paper seeks to explain the fit between numerable variables of technology strategy and its boundary conditions by the degree of conherence $(C O(T S))$ among the given variables. 
- In accordance with the principles of autonomy and recursion by Beer [6], systems are always a part of a superior system and therefore must adapt themselves to the overall objectives of this superior system ([8], [48]). Overall goal of a technology strategy is its contribution to the competitiveness of a company [15]. Thus the fit of a technology strategy can be determined by the level of contribution to the competitiveness of the enterprise $(C C(T S))$. According to Forrest ([31], [32]), structural dependencies arise when multiple elements of a system access the same infrastructure. With increasing structural dependencies the risk of instability of the system increases. Technology strategies need financial, human and material resources for their implementation. The resources of companies are generally limited. Therefore, the distribution of the resources between the individual technology fields of the company must be reasonible, i.e. for the greatest benefit possible. Following this argumentation, a fitted technology strategy must possess the lowest »opportunity costs « possible. Opportunity costs can be understood as costs that arise if resources are allocated to a specific technology field, but would have generated more benefit in another field. The following example illustrates this situation: The unnecessary increase of technological performance level in a field of technology outside of the core competencies of a company harms the company in the sense that these resources are not available to another field, which might be closer to the targeted business of the company. Minimizing the opportunity costs of a technology strategy is consequently a significant contribution to the competitiveness $(C C(T S))$ of the company.

- Based on the »Law of requisite variety: variety can destroy variety « by Ashby [3], the internal complexity (variety) of viable systems corresponds with the complexity of their environment ([58], [65], [78]). Applied to the field of technology strategy this means: the higher the complexity of the environment affecting the decisions taken in the context of technology strategy, the greater the complexity (variety) of technology strategy itself has to be. To assess the fit of a technology strategy, the difference of the complexity of the technology strategy and the complexity of the environment $(C D(T S))$ is therefore applied as a criterion, cf. Figure 1: Complexity difference $(C D(T S))$ between technology strategy and environment, following Rief [58] Figure 1. Based on this criterion, the logic of the technology strategy increases, if the complexity of the technology strategy strongly corresponds with the complexity of the environment. If the complexity of the technology strategy complies with the complexity of the environment, then the fit of the technology strategy related to this criterion is maximum. Since complexity is always associated with various challenges, such as the reduction of efficiency, the fit of technology strategy reduces beyond this point.

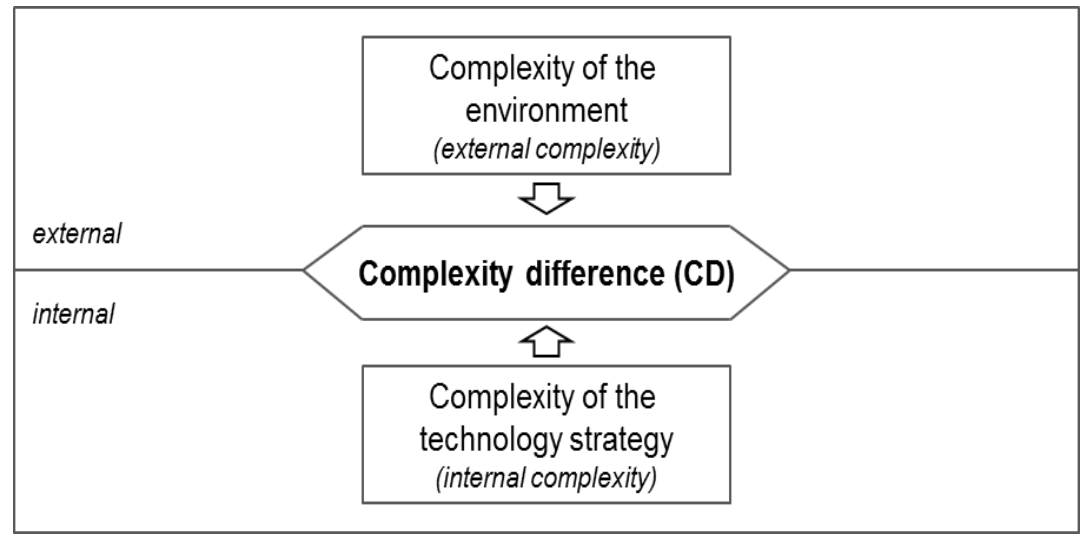

Fig. 1 Complexity difference $(C D(T S))$ between technology strategy and environment, following Rief [58]

The above-mentioned arguments adress the formulated questions concerning a reasonible positioning in the specific fields, a adequate level of detail of the technology strategy as well as reasonible distribution of resources to the different technology fields, cf. Figure 2.

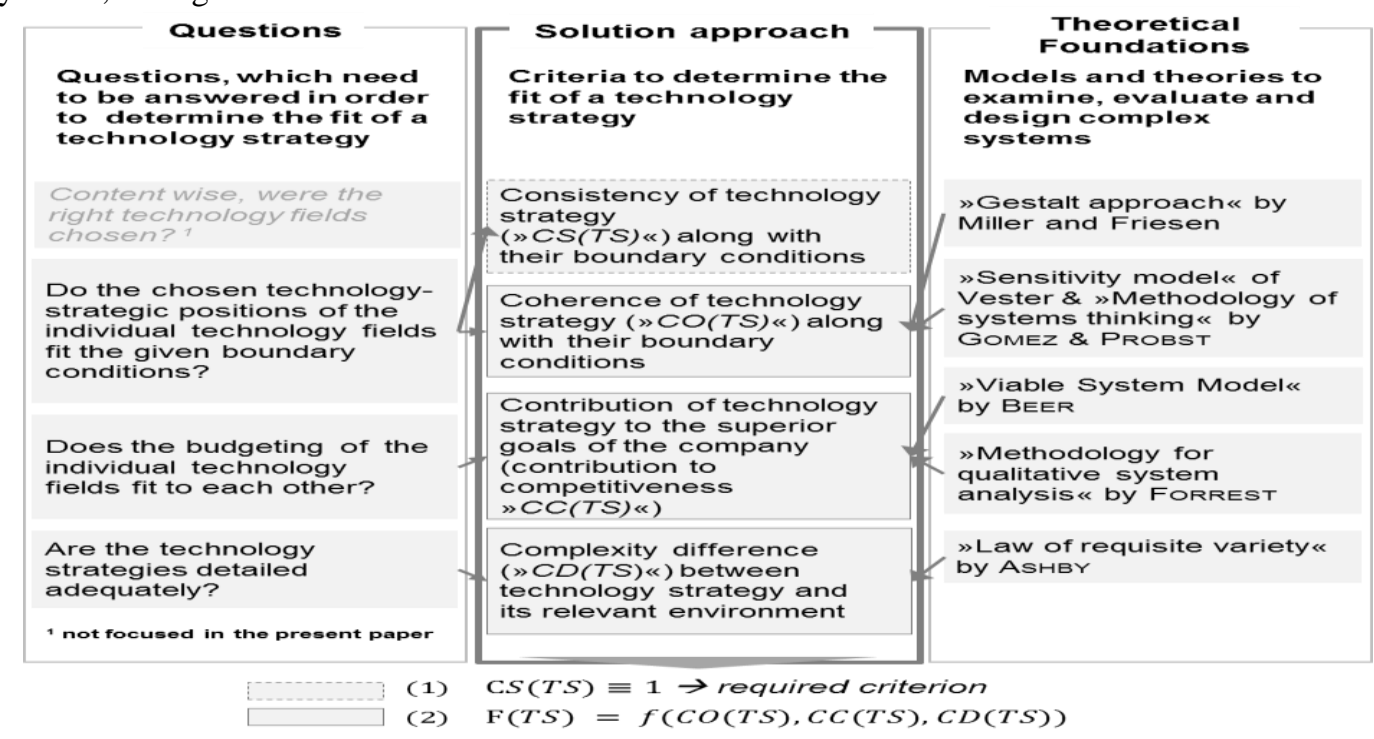

Fig 2 Contribution to determining the fit of a technology strategy of the different criteria 
To determine the fit of a technology strategy, the following equations can thus be derived:

(1) $\mathrm{CS}(\mathrm{TS}) \equiv \mathbf{1}$

(2) $\mathrm{F}(\mathrm{TS})=\mathrm{f}(\mathrm{CO}(\mathrm{TS}), \mathrm{CC}(\mathrm{TS}), \mathrm{CD}(\mathrm{TS}))$

\section{PROSPECT OF THE APPLICATION OF THE CRITERIA}

The previously derived criteria to determine the fit of a technology strategy, i.e., the consistency (CS(TS)), the coherence (CO(TS)), the contribution to competitiveness (CC(TS)) and the complexity difference (CD(TS)) of a technology strategy are still conceptual. To operationalise these criteria, procedures and sub-criteria were developed, which will be presented in the following section.

To determine the consistency of a technology strategy with its boundary conditions, criteria for exclusion were defined, e.g. for a technology pioneering positions, company-internal R\&D efforts have to take place. The criteria have to be matched with the chosen technology strategy positioning. To facilitate the matching, an exclusion matrix was developed, cf Figure 3.

\begin{tabular}{|c|c|c|c|c|c|c|c|}
\hline & 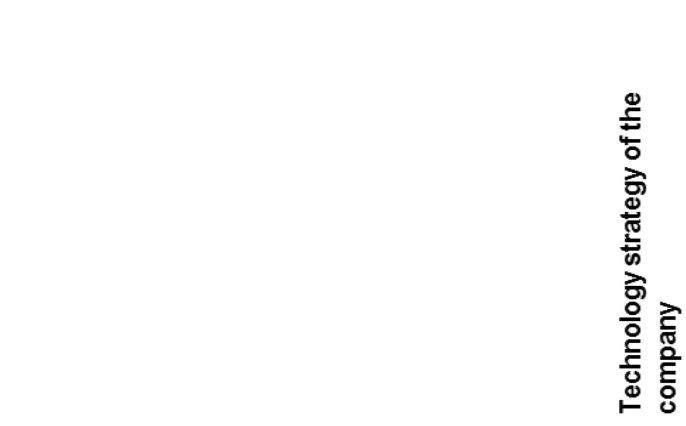 & 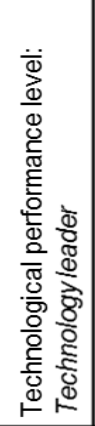 & 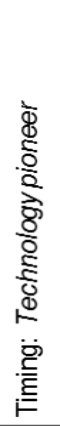 & 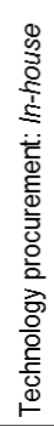 & 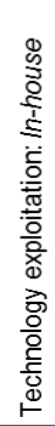 & 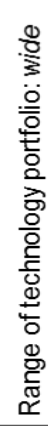 & 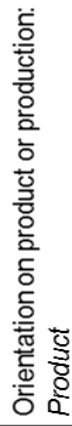 \\
\hline & $\begin{array}{l}\text { Exclusion criterion \& characteristic } \\
\text { of the company }\end{array}$ & 1 & 2 & 3 & 4 & 5 & 6 \\
\hline 1 & Divestment decision of the technology field: $n o$ & & & & & & \\
\hline 2 & External procurement concept of the t-field: yes & $\mathrm{x}$ & $\mathrm{x}$ & $x$ & & & \\
\hline 3 & Defined launch date for the product: no & & & & & & \\
\hline 4 & Corporate-internal R\&D-unit: no & $\mathrm{x}$ & $\mathrm{x}$ & $\mathrm{x}$ & & & \\
\hline 5 & Orientation on product or production: Product & & & & & & \\
\hline 6 & $\ldots$ & & & & & & \\
\hline
\end{tabular}

X: Contradictions, which need to be solved before determining the fit

Fig 3 Presentation of the exclusion matrix with an example

After securing that no contradiction can be found, the actual fit of the technology strategy can be determined. Firstly, the coherence of the technology strategy system, i.e. between the technology strategic choices and its relevant boundary conditions, has to be determined. To achieve this, the technology strategy as well as its relevant internal and external environment boundary conditions have to be displayed in form of variables. The variables were determined with the help of the cybernetic sensitivity model of Vester ([73], [74]), cf. Figure 4. 


\begin{tabular}{|c|c|c|c|c|c|}
\hline $\begin{array}{l}\text { Explanation } \\
\begin{array}{l}+ \text { positive influence existing } \\
- \text { negative influence existing } \\
+/- \text { Influence existing; statement on } \\
\text { direction not possible }\end{array}\end{array}$ & & & & & \\
\hline Growth orientation & + & + & & & + \\
\hline Relevance of technological differentiation & + & + & + & + & \\
\hline Research intensity & + & + & + & & + \\
\hline Parallelism of process operations & & + & & & \\
\hline Expansion of production capacity & & + & & + & \\
\hline Degree of innovation & + & + & + & & - \\
\hline Level of debt ratio & - & - & - & & \\
\hline Availability of resources & + & + & $+1-$ & + & + \\
\hline Level of qualification of employees & + & + & + & & \\
\hline Company age/ Development phase & - & - & - & & \\
\hline Intensity of competition & $+1-$ & $+1-$ & - & - & \\
\hline Threats of future competitors \& substitutes & - & - & - & & \\
\hline Dominance of customers & - & - & - & & \\
\hline Rate of price decrease & & + & & & \\
\hline Dominance of suppliers & - & - & - & + & \\
\hline Quality of collaboration & + & + & - & & \\
\hline$\cdots$ & + & & - & & \\
\hline
\end{tabular}

Fig 4 Variables of a technology strategy system (excerpt)

With the use of a cross-impact-matrix and cause-effect-diagrams, the role of the variables in the system, the number and direction of existing feedback loops as well as the network connectivity of the system can be analysed. With the help of this information, predictions are possible concerning the robustness (R(TS)), the ability of processing (AP(TS)) and the ability of self-regulation (AS(TS)) of the technology strategy system, which can be combined to derive predictions on the coherence of the technology strategy system $(\mathrm{CO}(\mathrm{TS}))$.

The contribution to competitiveness of a technology strategy (CC(TS)) can be derived by using an influence matrix which provides insights on how strong the link between technology strategy positions and the overall strategic goals of the company is. The consideration of opportunity costs, which arise whilst supporting one of the strategic goals, is crucial in this phase. The complexity difference of a technology strategy and its environment (CD(TS)) can be determined by comparing the variety of the technology strategy with the perceived complexity of the environment. The variety of the technology strategy can be determined by using an adapted version of the communality index of Martin \& Ishii ([49], [50]). The complexity of the environment can be identified based on the perception of the decision makers and supported by a developed questionnaire. This procedure was chosen due to the fact that strategic decision are always based on the perception of the decision maker [79].

\section{Conclusion}

References in theory and practice show that companies with an explicit technology strategy act more successful than companies without a long-term strategic technology plan. Furthermore, several studies showed, that the success contribution of a technology strategy stronly depends on its fit to the internal as wells as strategic and external boundary conditions. To provide companies with the opportunity to determine the fit of their previously derived technology strategy, expecially if boundary conditions change, we developed a way to determine the fit of a technology strategy. The determination of the fit is a first step to evaluate the effect of the drawn strategy and to derive measures to optimize it. As the fit of a technology strategy with its internal and external as well as strategic boundary conditions has been neglected in literature so far, in this paper we introduced criteria, based on which the fit of a technology strategy can be determined. Due to the high complexity and low concreteness of the task, we needed to apply a different way of thinking, apart from linear procedures. The concept of »fit as gestalt« as well as cyberntic reasoning proved to be a fruitful theoretical background to solve the problem. Due to this change of mindset, we reached to handle the complexity and to break down the fit of a technology strategy to distinct and measurable criteria: the consistency of a technology strategy, its coherence, its contribution to competitiveness of the company and its complexity difference to the relevant environment. We furthermore shortly provided some insight on how to operationalize these four criteria mainly based on the cybernetic sensitivity model.

Our approach shows, that the explanation and thus determination of the fit of a technology strategy with its relevant boundary conditions is possible in a quantitative way. It was goal of our research work to find a way to make the fit of a technology strategy within its ecosystem determinable. By applying the fit as gestalt perspective as well as cyberntic reasoning, this was made possible. 
However, this research is not without limitations. In terms of the abbreviation character of models, our research work only signs a first picture of the determination of the fit. This picture has to be detailed in further research work. Based on the understanding of a technology strategy in the way of the authors, we derived relevant internal and external influence factors on a technology strategy. First of all further research work is needed to deepen the understanding of a technology strategy. Secondly, more research is necessary to identify the factors and their intensity of influence on a technology strategy. Furthermore, the starting point for the determination of the fit with the help of the derived criteria is a previously derived technology strategy, i.e. technology fields are determined. The criteria do not reflect, whether the right technology fields were derived and have been positioned in. Our work rather assumes that the decision for the technology fields was done in the right way. Much research is needed in finding a way to integrate the decision for technology fields in the determination of fit. Most research work is needed to detail the criteria itself. This paper provided a possibility to determine the fit of a technology strategy in the first way. Detailing the criteria and finding a way to optimize the fit is a strong research task and should be in the focus of following research work.

\section{References}

[1].R.S. Rosenbloom, Ed., Technology Strategy: A Guide to the Literature, ser. Research on technological innovation, management and policy A research annual. Greenwich, United States: Jai Press, pp. 25-152, 1989.

[2].H.I. Ansoff and J.M. Stewart, "Strategies for a technology-based business", Harvard Business Review, pp. 71-84, 1967.

[3].W.R. Ashby, An introduction to cybernetics, London, United Kingdom: Methuen, 1957.

[4].Bea, F.X. and J. Haas, Strategisches Management, Konstanz, Germany: UVK, 2013.

[5].S. Beer, Kybernetik und Management, Hamburg, Germany: Fischer, 1962.

[6].S. Beer, Kybernetische Führungslehre (English title: The Brain of the Firm), Frankfurt a. M., Germany: Herder \& Herder, 1973

[7].S. Beer, The heart of the enterprise, Chichester, United Kingdom: John Wiley \& Sons, 1979.

[8].S. Beer, Diagnosing the system for organizations, Chichester, United Kingdom: John Wiley \& Sons, 1985.

[9].M. Beer, S. C. Voelpel, M. Leibold, and E. B. Tekie, "Strategic management as organizational learning: Developing fit and alignment through a disciplined process", Long Range Planning, vol. 38, no. 1, pp. 445-465, 2005.

[10]. T. Berger, „Methode zur Entwicklung und Bewertung innovativer Technologiestrategien“, Doctor Thesis, Universität Paderborn, Paderborn, Germany, 2006.

[11]. M. M. J. Berry and J. H. Taggart, "Combining technology and corporate strategy in small high tech firms", Research Policy, vol. 26, no. 7-8, pp. 883-895, 1998.

[12]. V. Binder and J. Kantowsky, Technologiepotentiale. Neuausrichtung der Gestaltungsfelder des strategischen Technologiemanagements, Wiesbaden, Germany: DUV, 1996.

[13]. R. K. F. Bresser, Strategische Managementtheorie, Walter de Gruyter: Berlin, Germany, 1998.

[14]. V. Brink, "Verfahren zur Entwicklung konsistenter Produkt- und Technologiestrategien“, Doctor Thesis, Universität Paderborn, Paderborn, Germany, 2010.

[15]. H. Brodbeck, Strategische Entscheidungen im Technologie-Management. Relevanz und Ausgestaltung in der unternehmerischen Praxis, Zürich, Switzerland: Industrielle Organisation, 1999.

[16]. R.S. Rosenbloom, Ed., Technology strategy: An evolutionary process perspective, ser. Research on technological innovation, management and policy A research annual. Greenwich, United States: Jai Press, pp. 1-25, 1989.

[17]. R.C. Dorf, Eds., Design and Implementation of Technology Strategy: An Evolutionary Perspective, ser. The technology management handbook. Boca Raton, United States: CRC Press LLC, pp. 16.1-16.17, 1999.

[18]. A. N. Chester, "Aligning technology with business strategy”, Research Technology Management, vol. 37, no. 1, pp.1-12, 1994.

[19]. K. Clarke, D. Ford, M. Saren and R. Thomas, “Technology strategy in UK firms”, Technology Analysis \& Strategic Management, vol. 7, no. 2, pp.169-191, 1995.

[20]. B. Clemson, Cybernetics: A New Management Tool, Amsterdam, Netherlands: Abacus Press, 1991.

[21]. R. Cooper, "Product Innovation and Technology Strategy", Research Technology Management, vol. 43, no. 1, pp.3841, 2000.

[22]. C. Davis, Managing Through Metrics: The Other Sides of Smart. 2013. [Online]. Available: http://www.metisstrategy.com/wp/wpcontent/uploads/2013/03/Managing-Through-Metrics-The-Other-Sides-ofSMART-Metis-Strategy-Chris-Davis-March-2013-Full.pdf. Accessed: Oct. 05, 2014.

[23]. M. Dodgson and R. Rothwell, “Technology Strategy in Small Firms”, Journal of General Management, vol. 17, no. 1, pp. 45-55, 1991.

[24]. M. Ehrat, „Kompetenzorientierte, analysegestützte Technologiestrategieerarbeitung“, Doctor Thesis, Universität St. Gallen, St. Gallen, Switzerland, 1997.

[25]. C. Feldmann, Strategisches Technologiemanagement. Eine empirische Untersuchung am Beispiel des deutschen Pharma-Marktes 1990 - 2010, Wiesbaden, Germany: DUV, 2007.

[26]. J. Fischer, Technologie und Wettbewerbsvorteile. Grundzüge einer Theorie des wertorientierten strategischen Technologiemanagements, Wiesbaden, Germany: DUV, 2002.

[27]. P. Flachskampf, „Beiträge zur systemorientierten Managementforschung mit kybernetischen Verfahren zur Gestaltung organisatorischer Systeme unterschiedlicher Rekursionsebenen“, Doctor Thesis, RWTH Aachen, Aachen, Germany, 2011. 
[28]. S. C. Fleming, "Using Technology for Competitive Advantage”, Research-Technology Management, vol. 34, no. 5, pp. 38-41, 1991.

[29]. D. Ford and C. Ryan, "Taking Technology to Market”, Harvard Business Review, vol. 59, no. 2, pp. 117-126, 1981.

[30]. D. Ford, "Develop your Technology Strategy", Long Range Planning, vol. 21, no. 5, pp. 85-95, 1988.

[31]. B. Williams and I. Imam, Eds., Evolutionary and Behavioral Characteristics of Systems, ser. Systems Concepts in Evaluation. An expert anthology. Point Reyes, United States: American Evaluation Association, pp. 197-214, 2006.

[32]. J. Forrest, “A System-Based, Qualitative Inference Method of Heuristics for Foresight and Futures Studies”, Doctor Thesis, Leeds Metropolitan University, Leeds, United Kingdom, 2009.

[33]. J. Friar and M. Horwitch, "The emergence of technology strategy", Technology in Society, vol. 7, no. 2-3, pp. 143$178,1985$.

[34]. A. Gomeringer, „Eine integrative, prognosebasierte Vorgehensweise zur strategischen Technologieplanung für Produkte“, Doctor Thesis, Universität Stuttgart, Stuttgart, Germany, 2007.

[35]. P. Gomez, Die kybernetische Gestaltung des Operations Managements. Eine Systemmethodik zur Entwicklung anpassungsfähiger Organisationsstrukturen, Bern, Switzerland: Haupt, 1978.

[36]. P. Gomez and G.J.B. Probst, Die Praxis des ganzheitlichen Problemlösens. Vernetzt denken, unternehmerisch handeln, persönlich überzeugen, Bern, Switzerland: Haupt, 1999.

[37]. F. Heylighen, "Cybernetics and second order cybernetics", Encyclopedia of physical science \& technology, vol. 2001, no. 4, pp. 155-170, 2001.

[38]. C.W. Hofer and D. Schendel, Strategy formulation. Analytical concepts, St. Paul, United States: West Pub. Co., 1978.

[39]. Y.-A Huang., H.-J. Chung and C. Lin, "R\&D sourcing strategies: Determinants and consequences", Technovation, vol. 29 , no. 3 , pp. 155-169, 2009.

[40]. M. C Jackson, “An appreciation of Stafford Beer's „Viable System “e viewpoint on managerial practice”, Journal of Management Studies, vol. 25, no. 6, pp. 557-573, 1988.

[41]. M. Klein, Erfolgsfaktoren technologieorientierter Wettbewerbsstrategien. Eine modellbasierte Analyse der Wettbewerbswirkungen forschungsintensiver Produktinnovationen, Berlin, Germany: Duncker \& Humblot, 1998.

[42]. H. Tschirky, Ed., Externe Technologie-Akquisition, ser. Technologie-Management. Idee und Praxis. Zürich, Switzerland: Industrielle Organisation, pp. 437-476, 1998.

[43]. M. Levin-Rozalis, "Cybernetics: A possible solution for the "knowledge gap" between "external" and "internal" in evaluation processes", Evaluation and Program Planning, vol. 33, no. 4, pp. 333-342, 2010.

[44]. S. Liao, "Technology management methodologies and applications", Technovation, vol. 25, no. 4, pp. 381-393, 2005.

[45]. K. Macharzina and J. Engelhard, „Internationalisierung der Unternehmenstätigkeit. Vorüberlegungen zur Konzeption eines Forschungsprogramms“, Universität Hohenheim, Stuttgart, Germany, 1984.

[46]. K. Macharzina and J.Wolf, Unternehmensführung. Das internationale Managementwissen; Konzepte - MethodenPraxis, Wiesbaden, Germany: Gabler, 2010.

[47]. M. A. Maidique, M. Tushman and W. L. Moore, Corporate Strategy and Technology Policy. Readings in the management of innovation, Cambridge, United States: Ballinger, 1982.

[48]. F. Malik, Strategie des Managements komplexer Systeme. Ein Beitrag zur Management-Kybernetik evolutionärer Systeme, Bern, Switzerland: Haupt, 2008.

[49]. M. V. Martin and K. Ishii, Eds., Design for Variety: A Methodology for Understanding the Costs of Product Proliferation, ser. Design Theory and Methodology. Irvine, United States, 1996.

[50]. M. V. Martin and K. Ishii, Eds., Design for Variety: Development of Complexity Indices and Design Charts, ser. Advances in Design Automation. Sacramento, United States, 1997.

[51]. D. Miller, "Strategy-Making in Context: Ten Empirical Archetypes", Journal of Management Studies, vol. 14, no 3, pp. 253-280, 1977.

[52]. D. Miller, "Evolution and revolution: A quantum view of structural change in organizations", Journal of Management Studies, vol. 19., no 2, pp. 131-151, 1982.

[53]. M. E. Porter, “What is strategy?”, Harvard Business Review, vol. 1996, pp. 61-78, 1996.

[54]. G. J. Probst, Integriertes Management. Bausteine des systemorientierten Managements, Bern, Switzerland: Haupt, 1985.

[55]. G. Probst and P. Gomez, Vernetztes Denken. Unternehmen ganzheitlich führen, Wiesbaden, Germany: Gabler, 1989.

[56]. G. Probst and P. Gomez, Vernetztes Denken. Ganzheitliches Führen in der Praxis, Wiesbaden, Germany: Gabler, 1991.

[57]. R. M Rieck and K. E. Dickson, “A model of technology strategy”, Technology Analysis \& Strategic Management, vol. 5, no. 4, pp.397-412, 1993.

[58]. A. Rief, Entwicklungsorientierte Steuerung strategischer Unternehmensnetzwerke, Wiesbaden, Germany: Gabler, 2008.

[59]. E. B. Roberts, Strategic Management of Technology: Global Benchmarking (Initial Report). Working Paper \#3640. Cambridge, United States: MIT, $\quad 1993 . \quad$ [Online]. https://ia600305.us.archive.org/8/items/strategicmanagem00robe/strategicmanagem00robe.pdf. Accessed: Oct. 05, 2014.

[60]. M. Santala and P. Parvinen, "From strategic fit to customer fit", Management Decision, vol. 45, no. 3, pp. 582-601, 2007. 
[61]. C. Scholz, "Corporate culture and strategy - the problem of strategic fit", Long Range Planning, vol. 20, no. 4, pp. 78-87, 1987.

[62]. G. Schreyögg, Unternehmensstrategie. Grundfragen einer Theorie strategischer Unternehmensführung, Berlin, Germany: Walter de Gruyter, 1984.

[63]. G. Schuh; Ed., Strategisches Innovationsmanagement, ser. Innovationsmanagement. Berlin, Germany: Springer, pp. 17-57, 2012.

[64]. G. Schuh and S. Klappert, Eds., Technologiestrategie, ser. Technologiemanagement. Berlin, Germany: Springer, pp. 55-88, 2011.

[65]. M. Schwaninger, "Systemtheorie. Eine Einführung für Führungskräfte, Wirtschafts- und Sozialwissenschafter", Institut für Betriebswirtschaft an der Hochschule St. Gallen, St. Gallen, Switzerland, 2004.

[66]. N. Strecker, "Innovation strategy and firm performance. An empirical study of publicly listed firms", Karl-FranzensUniversität, Graz, 2009.

[67]. N. Thongpapanl, "The changing landscape of technology and innovation management: An updated ranking of journals in the field", Technovation, vol. 32, no. 5, pp. 257-271, 2012.

[68]. H. Tschirky, Ed., Konzept und Aufgaben des integrierten Technologiemanagements, ser. Technologie-Management. Idee und Praxis. Zürich, Switzerland: Industrielle Organisation, pp. 193-394, 1998.

[69]. H. Ulrich and W. Krieg, St. Galler Management-Modell, Bern, Switzerland: Haupt, 1974.

[70]. H. Ulrich and G. Probst, Anleitung zum ganzheitlichen Denken und Handeln. Ein Brevier für Führungskräfte, Bern, Switzerland: Haupt, 1988.

[71]. N. Venkatraman and J. C. Camillus, "Exploring the concept of "fit" in strategic management", Academy of management review, vol. 9, no. 3, pp. 513-525,1984.

[72]. N. Venkatraman, "The concept of fit in strategy research: Toward verbal and statistical correspondence", Academy of management review, vol. 14, no. 3, pp. 423-444, 1989.

[73]. F. Vester, "The Biocybernetic Approach as a Basis for Planning Our Environment", Systems Practice, vol. 1, no. 4, pp. 399-413, 1988.

[74]. F. Vester, "The art of interconnected thinking. Ideas and tools for a new approach to tackling complexity", München, Germany: MCB Pub, 2012.

[75]. N. Wiener, Cybernetics. Or control and communication in the animal and the machine, New York, United States: M. I. T. Press, 1948.

[76]. P. White, "Building a sustainability strategy into the business", Corporate governance, vol. 9, no. 4, pp. 386-394, 2009.

[77]. B. Wolfrum, Strategisches Technologiemanagement, Wiesbaden, Germany: Gabler, 1994.

[78]. J. Wolf, Organisation, Management, Unternehmensführung. Theorien und Kritik, Wiesbaden, Germany: Gabler, 2005.

[79]. M. Yasai-Ardekani, "Effects of Environmental Scarcity and Munificence on the relationship of context to organizational structure", The Academy of Management Journal, vol. 32, no. 1, pp. 131-156, 1989.

[80]. S. A. Zahra and J. G. Covin, "Business Strategy, Technology Policy and Firm Performance", Strategic Management Journal, vol. 14, no. 6, pp. 451478, 1993.

[81]. S. A. Zahra, "Technology Strategy and New Venture Performance: A study of corporate-sponsored and independent biotechnology ventures", Journal of Business Venturing, vol. 11, no. 4, pp. 289-321, 1996.

[82]. S. A. Zahra, "Technology strategy and financial performance: Examining the moderating role of the firm's competitive environment”, Journal of Business Venturing, vol. 11, no. 3, pp. 189-219, 1996.

[83]. E. J. Zajac, M. S. Kraatz and R. K. F. Bresser, "Modeling the dynamics of strategic fit: A normative approach to strategic change", Strategic Management Journal, vol. 21, no. 4, pp. 429-453, 2000. 